${ }^{\circ}$ Entomologica Fennica. 10 December 1998

\title{
Mobility, population size and life time pattern of Carabus glabratus (Coleoptera, Carabidae) under extreme northern forest conditions.
}

\author{
Vesa Vainikainen, Juhani Itämies, Erkki Pulliainen and Paavo Tunkkari
}

Vainikainen, V., Itämies, J., Pulliainen, E. and Tunkkari, P. 1998: Mobility, population size and life time pattern of Carabus glabratus (Coleoptera, Carabidae) under extreme northern forest conditions. - Entomol. Fennica 9: 217-224.

The study was carried out in the Värriötunturi fell area $\left(67^{\circ} 44^{\prime} \mathrm{N}, 29^{\circ} 37^{\prime} \mathrm{E}\right)$ under northern taiga forest conditions. The habitat, a Pinus heath is extremely poor and monotonous. Altogether 196 pitfall traps 10 metres apart $(\varnothing 8.5 \mathrm{~cm}$, height $10.3 \mathrm{~cm}$, with a lid $5 \mathrm{~cm}$ above the trap) arranged in a quadrat were used in 1991, and the same field with an additional 40 traps placed one trap at each end of a two-metre wall was used from 1992 to 1994. The individuals of Carabus glabratus were marked with a small label cut off from a traffic sign sticker in 1991 and 1992. Only these captured and marked ones were recorded in the following years. In 1994 the trapping was done by killing the beetles. 524 individuals were marked. Males dominated in both years. The recapture proportion was significantly higher for the beetles marked in 1992 than for those of the previous year. The marked beetles were recaptured within four days on average. The estimated maximal population size in 1991 was 1400 individuals, occurring at the beginning of July, while in 1992 it was 3000 exx., in the middle of June. About 15\% of the beetles marked in 1991 were caught at least once during the year of marking. Two years after marking, the proportion of recaptures decreased to $2 \%$, but one male marked in 1991 was still captured in 1994.

Vesa Vainikainen and Juhani Itämies, Zoological Museum, BOX 333, FIN90571 Oulu, Finland.

Eekki Pulliainen and Paavo Tunkkari, Department of Biology, University of Oulu and Värriö Subarctic Research Station, University of Helsinki, P.O. BOX 333, FIN-90571 Oulu, Finland.

Received 10 October 1996, accepted 15 November 1997

\section{Introduction}

Ground beetles are usually long-legged, fast-moving insects (Chinery 1988) which thrive on the ground, where they can be found under stones and trees (Koch 1989). It has been stated that largesized carabids favour relatively heterogenic habitats (Grüm 1990). A certain vegetation does not 


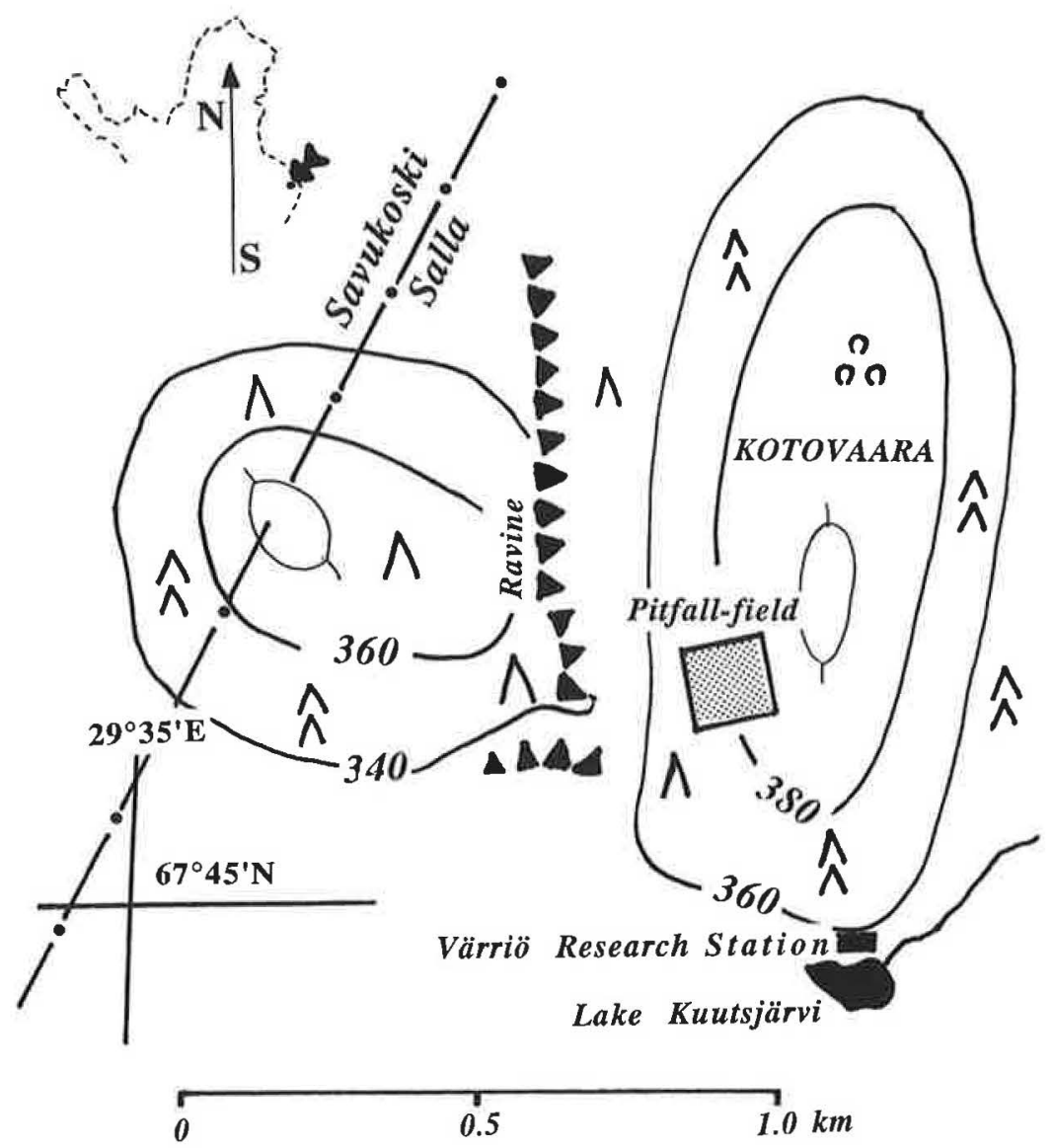

Fig. 1. The study area. Coordinates $=$ Grid $27^{\circ} \mathrm{E}$ and height above sea level. guarantee the occurrence of a species in a given area, however, as habitat selection depends on both the vegetation and the presence of other ground beetle species (Thiele 1977). Generally, the microhabitat demands of many northern taiga invertebrates are still poorly known (Niemelä et al. 1988).

The composition of ground beetle communities has often been studied with either random samples or with pitfall traps (Greenslade 1963, Grüm 1973, 1990, Reise \& Weidemann 1975, Luff 1975, Loreau 1985, Niemelä et al. 1986, Desender 1988, Niemelä 1990, Niemelä et al. 1992). The population size is influenced by both abiotic factors, e.g., temperature and food, and biotic factors, e.g. competition, predators and parasites (Price 1975, Szujecki 1987). The impact of abiotic factors on the population dynamics of carabids is less marked than that of biotic ones (Thiele 1977).

Our target animal was Carabus glabratus (Payk.), a carabid beetle which is widespread in Central, Northern and Eastern Europe. It is about
22-30 mm long, concave and usually coal black, sometimes with faint bluish tint. It can be distinguished from its close relative $C$. violaceus $\mathrm{L}$. by the two spines in the second segment of the labial palps (Lindroth 1945, 1949, 1985, Freude et al. 1976, Harde et al. 1984, Trautner \& Geigenmüller 1987, Koch 1989).

The aim of this article is to present data concerning the mobility, population size and life time pattern of Carabus glabratus during four years in the Värriötunturi fell area of E Finnish Forest Lapland, i.e. under extreme northern forest conditions.

\section{Material and methods}

\subsection{The Värriötunturi area}

The Värriötunturi fell area (Grid $27^{\circ} \mathrm{E} 752: 61$ ) in E Finnish Lapland (Fig. I) forms part of the Värriö Nature Reserve and is located close to the Russian border. In summer 1991 
a trap network was set up close to the Värriö Subarctic Research Station. The area had a tree layer of young saplings of pine (Pinus sylvestris) and birch (Betula pubescens) with an old pine heath forest. The field layer was dominated mainly by Vaccinium myrtillus, Calluna vulgaris, Empetrum hermaphroditum. Cladonia spp. is typical in ground layer, but severely suffering by grazing of reindeer. The habitat is an extremely poor, monotonous one. The substrate is tightly packed gravel, which is easily permeable to water. There is a thick permanent layer of snow on the ground in winter.

\subsection{Trapping}

The network was composed of 196 pitfall traps, each with a lid fastened with a nail about $5 \mathrm{~cm}$ above it $(\varnothing 8.5 \mathrm{~cm}$, height $10.3 \mathrm{~cm}$ ). They were deposited in a square measuring $140 \mathrm{~m} \times 140 \mathrm{~m}$, i.e. they were located $10 \mathrm{~m}$ apart in both directions. Each trap was coded by number-letter symbol (Al-N14). The field area, referred to below as the main field, was surrounded by red plastic ribbon in order to keep the reindeer out. The animals were collected alive from 1991 to 1993 (22 days in 1991 and 1992, 38 days in 1993 and 67 days in 1994). In the last summer 1994 trapping was done by killing the beetles with water added to the jars. Additional traps were placed around the main field in the summer 1992 and were provided with a metallic wall (length $220 \mathrm{~cm}$, height $10 \mathrm{~cm}$ ) in order to make the catching more effective, a pitfall trap of width $11.5 \mathrm{~cm} \times 8.5 \mathrm{~cm}$ and height $7.3 \mathrm{~cm}$ was dug at either end of each wall. Altogether 20 walls with 40 traps were placed around the main field at a distance of $50 \mathrm{~m}$ from it.

The traps were emptied twice a day in 1993 and 1994, starting in the morning around at 07.30 and the afternoon round at 18.00. In 1991 and 1992 the traps were also emptied in the evening, beginning at 23.00. The fieldwork was started soon after the snow had melted and finished when the activity of the beetles had clearly decreased (about the middle of July, see Pulliainen et al. 1993).

\subsection{Marking of beetles}

The beetles were marked using a piece of orange traffic sign sticker (Scotchlite ${ }^{\text {TM }}$ Reflective sheeting $3 \mathrm{M}$ ) meant for outdoor use, and also with blue paint (Artline 440). The colours were chosen so as to be sufficiently striking in to make it easier to observe marked animals in the field. Numbers were printed on the sticker shield and cut out beforehand to make labels of size $2.5 \mathrm{~mm} \times 5 \mathrm{~mm}$. The marking methods were tested in the laboratory on specimens of Tenebrio molitor Linnaeus and Carabus nemoralis Müller. Both marking methods seemed to be workable under laboratory conditions, but the paint rapidly turned out to be unsuitable in the field and its use was discontinued after the first year, so that only traffic sign stickers were used.

The beetles were lifted from the pitfall traps into a minigrip plastic bag with the aid of special equipment con- structed from a film jar. The bag there had a hole in it through which the label was placed on the right elytra. Moist animals were dried before marking. After marking, the animal was released one metre away from the trap, always pointing towards the centre of the field. The beetles were marked in 1991 and 1992. Before marking, the animal was held between the fingers for species identification. In this connection they often sprayed some secretion from their abdomen, which caused a sharp pain if it came into contact with the marker's face (see also Trautner \& Geigenmuiller 1987). The contents of their crop, which they vomited during the marking, also had a powerfull smell and quickly soiled the bag. It also aroused irritation in those individuals placed inside the bag, and therefore the marking was done as quickly as possible and the bag was cleaned repeatedly.

\subsection{Reliability of the data}

The reliability of the results for 1991 is affected slightly by the fact that we did not recognise the presence of an other Carabus species, $C$. violaceus $\mathrm{L}$. Our observations nevertheless show that the numbers of the latter were low (around $5 \%$ of those of $C$. glabratus, Vainikainen et al. unpubl. data). Only one $C$. violaceus was recaptured in the 1992 collection.

Marking-recapture models work on the assumption that the marking and release itself do not alter the activity of the target animal. Alternatively the marking may increase ("traphappiness') or reduce the probability of recapture (Gall 1984a). The low recapture figures in the present case could indicate some harmful effect of the marking upon the carabids. One might imagine that the paint (based on spiritus) might have increased mortality, this method was abandoned the next year. On the other hand, even more poisonous marking methods have been used without noticing any increase in mottality, although dispersal increased (Greenslade 1965).

Striking marks may increase the predation and may even have an influence on the social rank of an individual (Gall 1984a). We used orange colour which is considered to serve as a warning colour in the insect world (see Wigglesworth 1964, Horn 1976, Gall 1984b), so that we assume that the marks did not increase predation.

\section{Results}

524 individuals of Carabus glabratus were marked in the main field in 1991-92. The proportion of males was higher than that of females in both years $\left(1991: \chi^{2}=4.588, \mathrm{p}<0.05, \mathrm{df}=1\right.$; year 1992: $\chi^{2}=12.642, \mathrm{p}<0.001$, df $=1$ ).

About $15 \%$ of the animals marked in 1991 were caught at least once later in the same year. Next year the recapture percentage was $16 \%$, but after the two years of marking the proportion of 

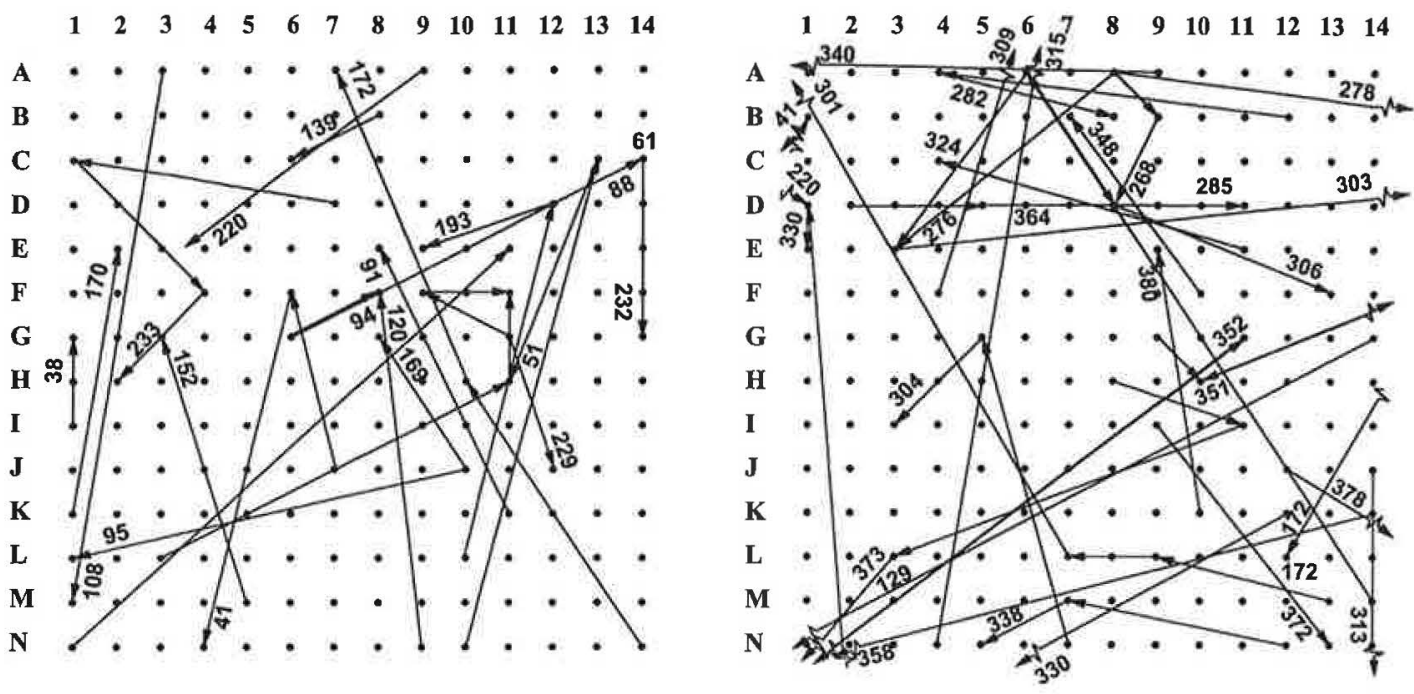

Fig. 2. Examples of the data on Carabus glabratus (Coleoptera, Carabidae) marked and recaptured in the Värriötunturi fell area of E Finnish Forest Lapland. Numbers refer to the individual marking numbers. The number beside a trap means that the individual in question was recaptured from the same trap. Left $=$ males marked and recaptured in 1991, right = males recaptured in 1992 nos. 41-268 marked in 1991, nos 276-380 marked in 1992. Auziczac end in an arrow means that the individual was recorded or marked in the additional traps (see Material and methods).

recaptures decreased to $2 \%$. One male marked in 1991 was still captured in 1994. No differences wcre observed between the recapture rates for males and females.

The proportion of animals marked in 1992 that were recaptured was significantly higher than for those marked in $1991(\mathrm{t}=3.7686, \mathrm{p}<0.001$, $\mathrm{df}=$ 522). Recapture rates differed significantly between males and females in $1992(\mathrm{t}=2.3048, \mathrm{p}<$ 0.05 , df $=255$ ), but not in 1993 or 1994 . The animals marked in 1991 seemed to survive over the winter much better than those marked in $1992(\mathrm{t}=$ $3.8426, \mathrm{p}<0.001, \mathrm{df}=522$ ).

\subsection{Mobility/Travelling distances}

The 1994 catch was left out of the results due to the small number of individuals $(n=2)$. The distances travelled varied from zero to $330 \mathrm{~m}$, where a zero value means that the individual was recaptured in the same trap where it was originally marked (Table 1). The differences between the distances covered by the males and females were not statistically significant. The personal best for a male was achieved by no. 351, marked in 1992. It travelled at least $170 \mathrm{~m}$ during one and a half hours $(1.9 \mathrm{~m} / \mathrm{min})$. Correspondingly, the fastest

Table 1. Mean and maximum travelling distances in meters, mean recapture times in days and mean travelling distances in meters per day of marked male and female Carabus glabratus individuals (Coleoptera, Carabidae) in the Värriötunturi fell area, E Finnish Forest Lapland. The years 1991 and $1992 \mathrm{a}=$ the main field, $1992 \mathrm{~b}=$ the main field with extra traps (see Material and methods).

\begin{tabular}{|c|c|c|c|c|c|c|c|c|}
\hline & \multicolumn{2}{|c|}{ Mean $\pm S D(N)$} & \multicolumn{2}{|c|}{ Maximum } & \multicolumn{2}{|c|}{$\begin{array}{l}\text { Recapture times } \\
\text { in days }\end{array}$} & \multicolumn{2}{|c|}{$\begin{array}{l}\text { Mean travelling } \\
\text { distance per day }\end{array}$} \\
\hline & Male & Female & Male & Female & Male & Female & Male & Female \\
\hline 1991 & $59 \pm 34(30)$ & $48 \pm 34(23)$ & 135 & 121 & 3.2 & 4.3 & 28 & 19 \\
\hline $1992 a$ & $49 \pm 39(58)$ & $42 \pm 38(22)$ & 170 & 120 & 2.9 & 7.7 & 22 & 9 \\
\hline $1992 b$ & $91 \pm 79(104)$ & $68 \pm 64(30)$ & 330 & 250 & 3.7 & 5.7 & 35 & 28 \\
\hline
\end{tabular}


Fig. 3. Size of the Carabus glabratus (Coleoptera, Carabidae) population and proportion of marked beetles in the Värriötunturi fell area in E Finnish Forest Lapland. White column = minimum population size; Grey column $=$ maximum population size; dotted line $=$ proportion of marked individuals.

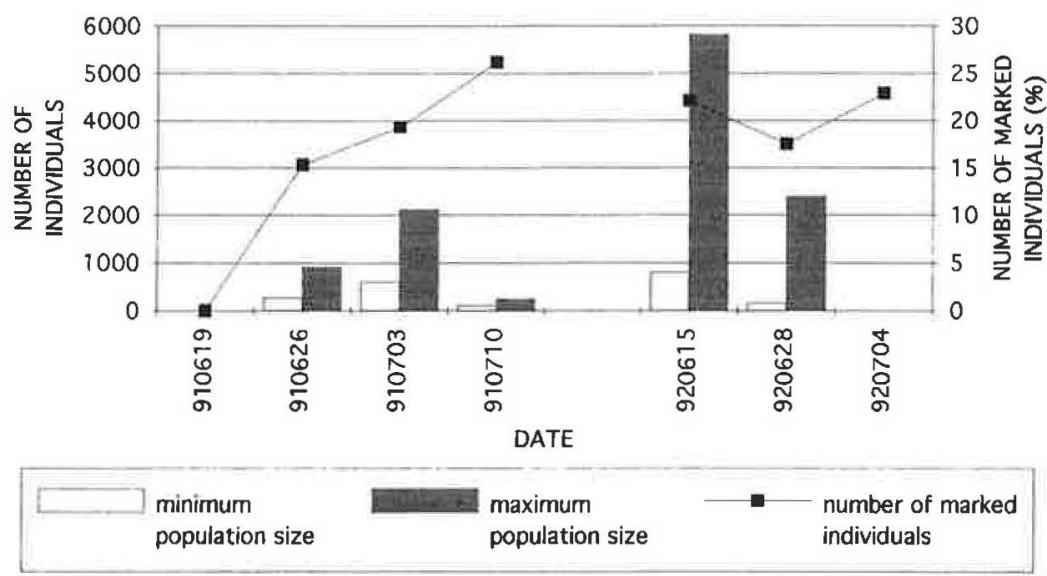

female was no. 281, also in 1992 which ran at least $190 \mathrm{~m}$ in fifteen hours.

The marked animals were recaptured within four days on average, the time for males being significantly shorter than that of females in 1992 $(t=2.479, p<0.05, d f=50)$. The real travelling distances must, of course, have been longer than those calculated from the shortest distance between consecutive trappings (Fig. 2).

\subsection{Population size}

The Jolly-Seber method (Krebs 1989) and the Jolly computer program (version 3.0) were used to estimate the population size. The estimates were done within an interval of one week in 1991 and 1992 (Fig. 3), and were based on the ratio between marked and recaptured animals in the main field (196 traps). The maximal size of population in 1991 was 1400 individuals at the beginning of July, and that in 1992 in the middle of June 3300 individuals. The proportion of marked animals recaptured increased evenly up to $26 \%$ during 1991 , whereas in 1992 there was a sudden drop to $17.5 \%$ in the middle of the marking period.

\section{Discussion}

Carabus glabratus lives in this area under extreme northern forest conditions: our plots were located at altitudes of 370-385 $\mathrm{m}$ a.s.1., while the coniferous timber line lies at $390 \mathrm{~m}$ a.s.l. and that of the mountain birch forest (regio subalpina) above it at $420 \mathrm{~m}$ a.s.1. The productivity of this pine forest community is generally low, and this is reflected in the growth rate and seed production of the trees (Pulliainen \& Lajunen 1984) and the composition and low density of the ground vegetation. The recapture rate in the present case remained low in years of marking (15.2-33.8\%), after which it naturally decreased steeply once no new individuals were being marked. Grüm (1975) marked $106 \mathrm{Ca}$ rabus glabratus individuals in an enclosure and recaptured almost all of them (95\%) in the same year, but this of course is not comparable with our results. Our low figures must indicate a large home range, as the marked animals did not stay in the area of the trapping field but wandered through it without being recaptured. It remains uncertain, however, how large an area $C$. glabratus is using here.

Success in the running competition for food makes it possible for $C$. glabratus to try to prolong its life, since these beetles have even reached a lifetime of five years under experimental conditions (Nickerl 1889, Kern 1912 after Thiele 1977). Our marking-recapture figures prove that Carabus glabratus lives for at least three years at Värriö. Similar result were obtained by Houston (1981) in Midlands of England. Although the numbers of individuals marked in 1991 that were recaptured in 1994 are small, the possibility is not excluded that, in view of the extensive home range, C. glabratus may live even longer than three years in this area. It would need more trapping over a much wider area to prove this.

The large population size in 1992 is also reflected in the total recapture figures $(28.8 \%)$. The 
pressure caused by the large numbers of individuals was most probably directed at the males, whose increased activity was observed in their greater recapture numbers than for females. On the other hand, specimens marked in 1992 survived overwinter worse $(6.4 \%$ recaptured 1993$)$ than those marked in 1991 (16.1\% recaptured 1992) (Table 2). In a closed population, Grüm (1975) observed that about a quarter of the animals survive over the winter. The present population was at its largest in 1992, which may have caused extra mortality or principally emigration.

The proportion of marked animals remained well below that of unmarked animals throughout. This shows that new individuals repeatedly migrated into the area. While in practice three generations occur at the same time, mobility is influenced by the ratio between these age classes, which have different demands for movement. After the first hibernation they are said merely to fill their energy stores, while after the second winter they start laying their eggs (Houston 1981).

Baars (1979) classified the patterns of movement of ground beetles into two categories: 1. random walking and 2 . direct movements. In the present case the $C$. glabratus specimens seemed to move about relatively randomly, without any detectable preferences in terms of direction. Ground beetles do not have any clear home range (Loreau 1993), nor could we find any clear home range at least on the scale of our field, and thus that their movements must be controlled more by the search for food and a suitable habitat (= shelter), as stated by Grüm (1971), Baars (1979) and Mols (1979). The additional traps around our basic field also showed the large radius over which $C$. glabratus moved. The present method may very easily alter their movements, even perhaps very complicated random ones, into direct ones as Loreau (1993) also notes.

Our observations of the distances which C. glabratus individuals moved per day are considerably greater than those presented by Thiele (1977), but fairly close to those reported by Scherney (1960), who found that Carabus cancellatus Ill., C. granulatus L. and C. auratus L. travelled $120 \mathrm{~m}$ during the first ten days, i.e. $12 \mathrm{~m}$ /day on average (in our study the average varied around thirty metres; see Table 1). The longest distance from the marking site in his material was $230 \mathrm{~m}$, observed after 50 days. Neumann (1971) found in his pitfall trappings that one Carabus problematicus Hbst. had wandered $77 \mathrm{~m}$ during one night after release, while in our results the longest distances observed were $170 \mathrm{~m} / 1.5$ hours (a male) and $190 \mathrm{~m} /$ 15 hours (a female). Ground beetles seem to be capable of moving long distances even within relatively short periods.

Four days as an average recapture time was consistent with the results of Grüm (1975). The significantly shorter recapture time in 1992 reflects the greater activity of the males. We must remember that the size of this population was at its greatest at that time, which presumably made the competition for females more severe. Ericson (1977) observed that the females of Pterostichus

Table 2. Yearly numbers of Carabus glabratus specimens marked and recaptured in the Värriötunturi fell area E Finnish Forest Lapland, r\% = recapture percentage.

\begin{tabular}{|c|c|c|c|c|c|c|c|c|c|}
\hline & \multirow[t]{2}{*}{ Marked } & \multicolumn{8}{|c|}{ Recaptured } \\
\hline & & 1991 & $r \%$ & 1992 & $r \%$ & 1993 & $\mathrm{r} \%$ & 1994 & $r \%$ \\
\hline \multicolumn{10}{|l|}{ Year 1991} \\
\hline Males & 151 & 23 & 15.2 & 25 & 16.1 & 1 & 0.6 & 1 & 0.6 \\
\hline Females & 116 & 18 & 15.5 & 18 & 15.5 & 4 & 3.5 & 0 & 0 \\
\hline Total & 267 & 41 & 15.3 & 43 & 16.1 & 5 & 1.9 & 1 & 0.4 \\
\hline \multicolumn{10}{|l|}{ Year 1992} \\
\hline Males & 157 & - & - & 53 & 33.8 & 10 & 6.4 & 1 & 0.6 \\
\hline Females & 100 & - & - & 21 & 21.0 & 5 & 5.0 & 0 & 0 \\
\hline Total & 257 & - & - & 74 & 28.8 & 15 & 5.8 & 1 & 0.4 \\
\hline
\end{tabular}


cupreus $\mathrm{L}$. and $P$. melanarius Ill. were more active than the males but entered the traps less often. After the two years of results we cannot generalize to the extent of stating that the males are more active than the females. The production of eggs makes the energy demands for females greater than for males, which forces the former to move about more in order to find more food (Grüm 1990).

The density of active ground animals such as ground beetles is difficult to estimate, although the marking-recapture method is usually used (Ericson 1977). Differences in the vegetation alone can affect the pattern of movement, which will be reflected in the results (Greenslade 1964). The weather also has a great effect on the activity, which remains low if it is cold (see Pulliainen et al. 1993). Although our figures for the numbers of $C$. glabratus individuals in different years are not totally comparable due to the different collecting periods, it is obvious that the population was largest in 1992. As summer proceeds some of the individuals die naturally, thus reducing the size of the population. The steep decrease in the numbers in late summer, on the other hand, is caused more by the decrease in active specimens than by mortality, the activity ceasing surprisingly early in the summer (see Pulliainen et al. 1993).

Thiele (1977) estimated the density of large ground beatles (i.e. Carabus spp.) to be about one individual per square metre, whereas Grüm (1975) observed that of C. glabratus to be three ind. $/ 100 \mathrm{~m}^{2}$. The observed population size is difficult to relate directly to the area of the field, for the reason mentioned earlier, i.e. the great activity and large home range of these animals. If we use as a basis the observations made by Grüm (1975), this would suggest that our field could accommodate 588 individuals $\left(19600 \mathrm{~m}^{2}=3\right.$ ind. $\left./ 100 \mathrm{~m}^{2}\right)$. This would mean theoretically that the estimated 3300 specimens (in 1992, see 3.2) could cover an area 5.5 times larger than our main field. The smaller the field is, the greater is the possibility of overestimating the population size (Loreau 1993). From how large an area the present field caught its animals is difficult to say, but our movement observations do not give us any reason to say that our results deviate very greatly from those of Grüm (1975).

The $C$. glabratus beetles have evidently se- lected a clear strategy under these hostile northern conditions. They concentrate their activities in summer into as short a period as possible and use the active period as effectively as possible, with the aid of great mobility, in order to find enough nutritious food and at the same time perhaps also water. Success in the latter respect is a prerequisite for the relevance of the former. Loreau (1985) also pointed out that under Nordic, harsh conditions, the activity period should be short and concentrated to summer.

Acknowledgements: We wish to thank the staff of Värriö Subarctic Research Station, who helped in many ways during the collecting of the material. Separate thanks are due to Pirkko Viro, Päivi Ollinmäki, Ahti Karusalmi and Pasi Reunanen for help of various kind. Jyrki Muona opened our eyes to the difference between Carabus glabratus and C. violaceus, for which we are gratefull. Financial support was gained from Oulun Luonnonystäväin Yhdistys, which is also warmly thanked. This is report no. 335 from the Värriö Subarctic Research Station of the University of Helsinki.

\section{References}

Baars, M. A. 1979: Patterns of movement of radioactive carabid beetles. - Oecologia (Berlin) 44: 125-140.

Chinery, M. 1988: Pohjois-Euroopan hyönteiset. - Tammi, Helsinki. 353 pp.

Desender, K. 1988: Spatial distribution of carabid beetles. - Revue d Ecologie et de Biologie du Sol 25: 101 113.

Ericson, D. 1977: Estimating population parametres of Pterostichus cupreus and P. melanarius (Colepoptera, Carabidae) on arable fields by means of capture-recapture. — Oikos 29: 407-417.

Freude, H., Harde, K. W. \& Lohse, G. A. 1976: Die Käfer Mitteleuropas. Band 2. Adephaga 1. - Goecke \& Evers, Krefeld. 302 pp.

Gall, L. F. 1984a: The effects of capturing and marking on subsequent activity in Boloria acronema (Lepidoptera, Nymphalidae), with a comparison of different numerical models that estimate population size. - Biol. Conservation 28: 139-154.

Gall, L. F. 1984b: Population structure and recommendations for conservation of the narrowly endemic alpine butterfly, Boloria arconema (Lepidoptera, Nymphalidae). - Biol. Conservation 28: 111-138.

Greenslade, P. J. M. 1963: Further notes on aggregation in Carabidae (Coleoptera), with special reference to Nebria brevicollis (F.). - Entomol. Mon. Mag. 99: 109-114.

Greenslade, P. J. M. 1964: The distribution, dispersal and size of a population of Nebria brevicollis (F.), with comparative studies on three other Carabidae. - J. Anim. Ecol. 33: 311-333. 
Greenslade, P. J. M. 1965: On the ecology of some British carabid beetles with special reference to life histories. - Trans Soc. Br. Entomol. 16: 149-179.

Grüm, L. 1971: Spatial differentation of the Carabus (Coleoptera, Carabidae) mobility. - Ekol. Polska 19: 1-34.

Grüm, L. 1973: Patterns of Carabus acrensis (Hbst.) distribution within different habitats. - Bulletin de l'Academie Polonaise des Sciences. Classe II. Serie des Sciences biologiques 21: 229-233.

Grüm, L. 1975: Mortality patterns in carabid populations. — Ecol. Polska 23: 649-665.

Grüm, L. 1990: Spatial distribution of males and females of Carabus acrensis (Hbst.) in the breeding season. - In: Stork, N. E. (ed.), The role of ground beetles in ecological and environmental studies: 277-287. Intercept. Andover.

Harde, K. W., Hammond, P. M. \& Severa, F. 1984: A field guide in colour to beetles. - Octopus Books, Czechoslovakia. $334 \mathrm{pp}$.

Horn, D. J. 1976: Biology of insects. - W.B. Saunders Company, Philadelphia.

Houston, W. W. K. 1981: The life cycles and age of Carabus glabratus Paykull and Carabus problematicus Herbst (Coleoptera, Carabidae) on moorland in northern England. - Ecol. Entomol. 6: 263-271.

Kern, P. 1912: Über die Fortpflanzung und Einbildung bei einigen Carabiden. - Zool. Anz. 40: 345351.

Koch, K. 1989: Die Käfer Mitteleuropas. 1. - Ökologie. Goecke \& Evers, Krefeld. 440 pp.

Krebs, C. H. 1989: Ecological methodology. - Harper \& Row, New York. 168 pp.

Lindroth, C. H. 1945: Die Fennoskandischen Carabidae. — Göteborgs Kungl. Vetens. Handl. B4 (1): 1-709.

Lindroth, C. H. 1949: Die Fennoskandischen Carabidae. — Göteborgs Kungl. Vetens. Handl. B4(3): 1-911.

Lindroth, C. H. 1985: The Carabidae (Coleoptera) of Fennoscandia and Denmark. - Fauna Entomol. Scand. 15: $1-225$.

Loreau, M. 1985: Annual activity and life cycles of carabid beetles in two forest communities. -- Holarctic Ecol. 8: 228-235.

Loreau, M. 1993: Occupation of space by the carabid beetle Abax ater. - Acta Oecologica 14: 247-258.

Luff, M. L. 1975: Some features affecting the efficiency of pitfall traps. - Oecologia (Berlin) 19: 345-357.

Mols, P. J. M. 1979: Motivation and walking behaviour of the carabid beetle Pterostichus coerulensis (L.) at different densities and distributions of prey. - Misc. $\mathrm{Pa}-$ pers Landb. Hogeschool Wageningen 18: 185-198.

Neumann, D. 1971: The temporal programming of development in the intertidal chironomid Clunio marinus (Diptera, Chironomidae). — Can. Entomol. 103: 315318.

Nickerl, O. 1889: Carabus auronitens Fab. Ein Beitrag zur Kenntnis vom Lebensalter der Insekten. - Stettin. Entomol. Z. 50: 155-163.

Niemelä, J. 1990: Spatial distribution of carabid beetles in the southern finnish taiga, the question of scale. - In: Stork, N. E. (ed.), The role of ground beetles in ecological and environmental studies: 143-1 55.

Niemelä, J., Halme, E., Pajunen, T. \& Haila, Y. 1986: Sampling spiders and carabid beetles with pitfall traps, the effect of increased sampling effort. - Ann. Entomol. Fennici 52: 109-111.

Niemelä, J., Haila, Y., Halme, E., Lahti, T., Pajunen, T. \& Punttila, P. 1988: The distribution of carabid beetles in fragments of old coniferous taiga and adjacent managed forest. — Ann. Zool. Fennici 25: 107-1 19.

Niemelä, J., Haila, Y., Halme, E., Pajunen, T. \& Punttila, P. 1992: Small-scale heterogenity in the spatial distribution of carabid beetles in the southem Finnish taiga. J. Biogeography 19: 173-181.

Price, P. W. 1975: Insect ecology. — John Wiley \& Sons, New York. 514 pp.

Pulliainen, E. \& Lajunen, L. H. J. 1984: Chemical composition of Picea abies and Pinus sylvestris seeds under subarctic conditions. — Can. J. For. Rs. 4: 214-217.

Pulliainen, E., Itämies, J., Jussila, P. \& Tunkkari, P. 1993: Phenology and habitats of Carabus glabratus Paykull (Coleoptera, Carabidae) in NE Finland. - Entomol. Fennica 4: 27-30.

Reise, K. \& Weidemann, G. 1975: Dispersion of predatory forest floor arthropods. - Pedobiologia 15: 106-128.

Scherney, F. 1960: Uber die Zu- und Abwanderung von Laufkäfern (Carabidae) in Feldkulturen. - Pflanzenschutz 12: 169-171.

Szujecki, A. 1987: Ecology and forest insects. — Polish Scientific Publishers, Warszawa. 600 pp.

Thiele, H.-U. 1977: Carabid beetles in their environments. A study on habitat selection by adaptations in physiology and behaviour. - Springer-Verlag, Berlin. 369 pp.

Trautner, J. \& Geigenmüller, K. 1987: Tiger beetles, ground beetles, illustrated key to the Cicindelidae and Carabidae of Europe. - Margraf., Aichtal. 488 pp.

Wigglesworth, V.B. 1964: The life of insects. - Weidelfeld and Nicolson, London. 359 pp. 